\title{
Behavioral Changes in Accessing Outpatient Care During the Covid-19 Pandemic
}

\author{
Perubahan Perilaku Akses Layanan Kesehatan Rawat Jalan di Masa Pandemi \\ Covid-19
}

\author{
Alfiah Hasanah ${ }^{1}$, Donny Hardiawan ${ }^{1}$, Jefani Marrosa ${ }^{1}$, Adlan Ramadhan ${ }^{1}$, Heriyaldi ${ }^{1}$, Estro Dariatno \\ Sihaloho ${ }^{1}$, Adiatma Yudistira $M^{1}$
}

${ }^{1}$ Departemen Ilmu Ekonomi, Fakultas Ekonomi dan Bisnis, Universitas Padjadjaran

Korespondensi: Alfiah Hasanah

E-mail: alfiah@unpad.ac.id

\begin{abstract}
Unwillingness to seek healthcare has been observed in citizens from many countries during the Covid-19 pandemic. Previous studies show that the changes in behavior are due to various reasons such as economic slowdown, loss of health insurance due to termination of employment, and fear of contracting the virus. This behavior may result in worsened health conditions, making a individual more susceptible to the virus. The supply side of health care is one of the things that should be considered in the discussion about access to health care in developing countries. This paper investigates access to the healthcare problem of Indonesians, discusses both the supply side and demand side by looking at the change of behavior due to the patients' fear of getting treatment during pandemic covid-19. We will serve this purpose through a small-scale survey and offer some insights from a statistical analysis perspective as well. Based on a survey from 588 respondents from the west Indonesia region, this study observes that the respondents' health condition shows no significant change before and during the Covid-19 pandemic era. On the other hand, the respondents' frequency of accessing outpatient healthcare proves to be significantly decreasing during the Covid-19 pandemic era, with $23,4 \%$ of the respondents stating that they avoid utilizing outpatient healthcare as an effort to avoid the Coronavirus. The frequency of using Kartu Indonesia Sehat to access outpatient healthcare also shows a significant decrease during this pandemic era.

Keywords: Covid-19, outpatient care, Healthcare access, paired t-test, univariate probit

Abstrak

Pada masa Pandemi Covid-19, masyarakat secara global menunjukkan perilaku enggan mengakses fasilitas kesehatan. Tinjauan literatur menunjukkan bahwa alasan utama dari perilaku tersebut meliputi penurunan aktivitas ekonomi, hilangnya jaminan kesehatan bagi masyarakat yang kehilangan pekerjaan, serta rasa takut yang berlebihan pada penularan virus. Hal ini dapat memperburuk kondisi kesehatan masyarakat. Namun, di Indonesia, terdapat beberapa kasus dimana pihak fasilitas kesehatan turut mempersulit akses layanan kesehatan bagi masyarakat di masa pandemi ini. Studi ini bertujuan untuk mengumpulkan informasi tentang perilaku masyarakat terkait permasalahan akses kesehatan di Indonesia di masa pandemic Covid-19, apakah bersumber dari penyedia fasilitas kesehatan, ataukah terdapat juga faktor rasa takut dari masyarakat. Tujuan tersebut akan dicapai melalui survei skala kecil, dan kami juga akan menawarkan beberapa pandangan berdasarkan uji statistik. Menurut data yang kami peroleh dari 588 responden, hasil analisis menunjukan bahwa tidak ada perubahan keluhan kesehatan yang signifikan pada saat sebelum Covid-19 dan pada saat pandemi Covid-19 terjadi. Namun, frekuensi rawat jalan mengalami penurunan yang signifikan di masa pandemic, dengan 23,4 persen responden beralasan tidak mengakses rawat jalan untuk menghindari penularan Covid-19. Kemudian, frekuensi menggunakan Kartu Indonesia Sehat untuk berobat jalan masyarakat masing-masing mengalami penurunan signifikan di masa pandemi Covid-19.

Kata kunci: Pandemi Covid-19, rawat jalan. akses fasilitas kesehatan, paired t-test, probit univariat
\end{abstract}




\section{Introduction}

According to the Indonesian Task Force for Covid-19 Response Acceleration data (Satgas Penanganan COVID-19), by January 26, 2021, there were 1,528 cases of Covid-19 in Indonesia, with 136 deaths and 81 recovered patients. By January 26, 2021, the number of cases sharply increased to $1,012,350$ cases, with 28,468 deaths and 820,356 recovered patients. This pandemic situation affects Indonesia's economy quite strongly. Indonesia Statistical Bureau (BPS) reported that the 2020 Q2 GDP contracted as much as 5.32 percent, the deepest contraction for Indonesia since the 1998 crisis. In line with this contraction, household consumption was also reported to decrease by 5.51 percent (National Economic Growth Impacted by COVID-19 in Q2/2020 - Bank Sentral Republik Indonesia, no date).

Adding to these economic problems, Indonesians have also had trouble regarding access to healthcare. According to the Ministry of Health data (BPJS Kesehatan, no date), by the year 2017, approximately 30 percent of the nation's people were still yet to be registered on Indonesia's National Health Insurance Program (JKN-KIS). Indonesia's 2018 National SocioEconomic Household Survey (Susenas) data shows that around 35.90 percent of Indonesia's population was still not covered by any form of health insurance. Likewise, data from the Indonesian Health and Social Security Agency (BPJS) for 2020 show that around 20\% of Indonesia's population was still not covered by National Health Insurance (JKN-KIS). From the healthcare capacity aspect, The World Bank reported that by 2017, Indonesia only had 1.2 hospital beds per 1000 people, a lower ratio compared to Malaysia (1.9), Vietnam (2.6), and Thailand (2.1). Indonesia's ratio for physicians per 1000 people was reported at 0.4 in 2018, also lower than its peers such as Malaysia (1.5),
Vietnam (0.8), and Thailand (0.8) (Deloitte Indonesia, 2020). This data highlights Indonesia's problem of healthcare capacity, even before the Covid-19 pandemic began.

Along with various economic and healthcare problems in this pandemic era, people's tendency to seek healthcare faces a notable decrease globally. The World Health Organization (WHO), through a survey involving 155 targeted countries in May, reported that various countries showed a decrease in healthcare activities, especially for Non-Communicable Disease (NCD) care such as cancer (in $42 \%$ of the countries), heart disease (in $31 \%$ of the countries), hypertension (in $53 \%$ of the countries) and diabetes (in $49 \%$ of the countries). The reasoning behind this decrease included care schedule cancellation, lack of public transportation, insufficient number of healthcare staff due to the pandemic, unavailability of needed medicine, and lack of adequate medical technology. This situation could be dangerous, as NCD patients that do not get their needed healthcare will be more vulnerable to the virus, and the WHO also found a correlation between the disruption of NCD care activities and the spread of Covid-19 cases. In the case of online health services, the WHO found developing countries to have less NCD online care available than developed countries.

Another report (NEJM Catalyst, 2020) dives into the case of the Adventist Health Lodi Memorial Hospital in the US that recorded a decrease in their patient volume, including patients that were already scheduled for treatments. In March, all of their stroke patients avoided going to the hospital and were too late to get their muchneeded tissue plasminogen activator (tPA) as a result. Meanwhile, the hospital's emergency care unit reported an increase in cardiac arrest cases at $45 \%$, indicating that patients had waited too long to seek care for their illness. The Emergency 
Design Collective team then found five main reasoning for the patients' behavior: the hospital was seen as an infectious place for Covid-19; patients were unaware of the risk mitigation measures that the hospital had been practicing; patients felt the need to be reminded by their health practitioners that they need to come to the hospital for treatments; the majority of the news reported hospital overcapacity due to the Coronavirus, and elderly patients tend to have no one to remind them to seek care. In line with these two reports, research from University College Dublin's Interdisciplinary Research Education and Innovation in Health Systems (IRIS) reported that $34 \%$ of Irish parents were aware that their children needed to seek healthcare, but were reluctant to let their children visit healthcare facilities due to fear of contacting the Coronavirus (Kearns, 2020).

From this background, it can be inferred that healthcare access, fear of contacting the Coronavirus, and economic difficulties are the main problems that should be assessed in this pandemic era, especially to ensure that people are getting access to healthcare that they need. Limited studies are focusing on people's behavior regarding access to healthcare in Indonesia during the Covid-19 pandemic is still rare. In Indonesia, the problem seems to lead more to the supply side, where healthcare facilities risk their patients' lives because they could not deliver a quick enough medical response with all the procedures that need to be taken due to Covid-19.

COVID-19 pandemic has changes paediatric emergency healthcare utilization and raise concerns regarding potential delays in seeking healthcare for babies and children (Conlon, C., McDonnell, T., Barrett, M. et al., 2021). Many children bear the impact of pandemic, lower access to health care centre means missing out on life-saving vaccinations increasing their risk of losing lives to pneumonia, diarrheal diseases, and other preventable diseases (Unicef, 2021).

This paper aims to bridge the gap and gather some knowledge on whether the healthcare access problem of Indonesians fully comes from the supply side, or, like some aforementioned cases in this section, if there also exists a change of behavior due to the patients' fear of getting treatment. We will serve this purpose through a small-scale survey and offer some insights from a statistical analysis perspective as well.

\section{Method}

Primary data through interviews and online surveys were collected for this study on 1-31 July 2020 , with the targeted sample being individuals aged 15 years old and older who were registered as JKN participants and those who were not. 8 indicators were used to assess our respondents' socio-economic condition: their highest education level, age, gender, household status, marriage status, place of residence, occupation, and ownership of health insurance. We also inquired about our respondents' health condition and their frequency of accessing outpatient and inpatient care, both before and during the Covid-19 pandemic. For each case of outpatient and inpatient care history, there were questions regarding the reasoning for not seeking healthcare and for not utilizing Indonesia's JKN-KIS program to seek healthcare, both before and during the Covid-19 pandemic.

In this research, 636 data were obtained from respondents who had filled out our research questionnaires and were spread across 22 provinces in Indonesia with the majority of respondents coming from West Java, DKI Jakarta, and West Sumatra. After processing the data, we dropped 48 respondents from our dataset due to the incompleteness of the data in the questionnaire. So, our clean dataset for this research included a total of 588 respondents. To identify statistical differences in our respondents' health condition and their inpatient and outpatient behavior before and during the Covid-19 pandemic, we applied the 
paired t-test method using Stata 14.0 software. This statistical test is used for interval/ratio data that has a normal distribution. Here are the following steps for conducting paired sample t-test:

1. Determine the hypotheses. Paired sample t-test has two competing hypotheses, the null hypothesis and alternative hypothesis, where:

- $H_{0}:(\mu 1-\mu 2)=0$ or $\mu 1=$ $\mu 2$

There's no difference in the sample before and during Covid-19 pandemic.

- $H_{1}:(\mu 1-\mu 2) \neq 0$ or $\mu 1 \neq$ $\mu 2$

There are differences in the sample before and during Covid-19 pandemic.

2. Choose the level of significance that will be used $(\alpha)$.

3. Calculate the degree of freedom $(n-1)$.

4. Calculate the t-table value by finding the meeting line between level of significance and the degree of freedom in the $t$ distribution value table.

5. Finding the value of the test statistic with the following formula:

$$
t=\frac{\underline{d} \cdot \sqrt{n}}{s_{d}} \text { or } t=\frac{\underline{d}}{s_{d} / \sqrt{n}}
$$

Where:

$n=$ the number of paired observations

$\underline{d}=$ the mean of the difference between

the paired or related observations

$s_{d}=$ the standard deviation of the differences between the paired or related observations

The standard deviation can be calculated as:

$s_{d}=\sqrt{\left[\frac{\sum_{i=1}^{n} d_{i}^{2}-\left(\sum_{i=1}^{n} d_{i}\right)^{2}}{n-1}\right\rfloor}$

6. The decision rule is to reject the null hypothesis if the computed value of $t$ is less than $-t_{\text {table }}$ or greater than $+t_{\text {table }}$ (Lind et al., 2012).

To answer the research objectives, we used outpatient access variables. The dummy variable is 1 if the respondent accesses outpatient care and 0 others. We use two research models to compare two periods or situations, first the period before the pandemic and the second during the pandemic. We also applied univariate probit regression to estimate how each of our respondents' socioeconomic factors could affect their tendency to access outpatient care, with robust standard errors to account for heteroscedasticity. This method is part of the binary response model, which is a regression with dependent variables having a value of 0 or 1 . The probit model is used for a dataset that does not have random sampling and is normally distributed. According to (Wooldridge, 2013), binary response models of the form can be drawn in the following equation:

$$
P(y=1 \mid x)=G(0+1 X i+\ldots+k X k=G(0+x \beta)
$$

Where $\mathrm{G}$ is the function taking on values between zero and one $(0<\mathrm{G}(\mathrm{z})<1)$ and $\mathrm{z}$ is the real number. In the probit model, $\mathrm{G}$ is the standard normal cumulative distribution function, which is expressed as an integral

$$
\mathrm{G}(\mathrm{z})=\phi(\mathrm{z})=-\infty \mathrm{z} \phi(\mathrm{v}) \mathrm{dv}
$$

For ethical considerations, this study has complied with all prerequisites enforced by Universitas Padjadjaran's ethical research standards.

\section{Findings}

Table 1 describes the characteristics of respondents. Around 55.95 percent of our respondents are $15-30$ years old, $61.90 \%$ lives in municipality area, $62.59 \%$ are female, $52.04 \%$ are single, $56.12 \%$ had listed in high school as their last completed education, $40.31 \%$ are student, 
$52.55 \%$ are children in their respective family structures, and $41.33 \%$ are registered in JKN-KIS program (non-PBI category). It has come to our interest that $25.34 \%$ of our respondents are still not registered in the government's JKN-KIS program. Our assessment of the respondents' health condition and outpatient care history before and during the Covid-19 pandemic is displayed in Table 2.

Descriptive statistics of the variables in this study are as shown in Table 1.

Table 1. Summary Statistics

\begin{tabular}{|c|c|c|c|}
\hline Variable & Freq. & Percent (\%) & Cum. (\%) \\
\hline \multicolumn{4}{|l|}{ Age } \\
\hline $15-30$ & 329 & 55.95 & 55.95 \\
\hline $31-45$ & 107 & 18.20 & 74.15 \\
\hline $46-60$ & 122 & 20.75 & 94.90 \\
\hline$>60$ & 30 & 5.10 & 100.00 \\
\hline Total & 588 & & \\
\hline \multicolumn{4}{|l|}{ Place of Residence } \\
\hline Municipality & 364 & 61.90 & 61.90 \\
\hline Regency & 224 & 38.10 & 100.00 \\
\hline Total & 588 & 100.00 & \\
\hline \multicolumn{4}{|l|}{ Sex } \\
\hline Female & 368 & 62.59 & 62.59 \\
\hline Male & 220 & 37.41 & 100.00 \\
\hline Total & 588 & 100.00 & \\
\hline \multicolumn{4}{|l|}{ Marriage Status } \\
\hline Divorced & 12 & 2.04 & 2.04 \\
\hline Married & 250 & 42.52 & 44.56 \\
\hline Single & 306 & 52.04 & 96.60 \\
\hline Widowed & 20 & 3.40 & 100.00 \\
\hline Total & 588 & 100.00 & \\
\hline \multicolumn{4}{|l|}{ Education } \\
\hline Does not attend school & 1 & 0.17 & 7.65 \\
\hline Elementary & 23 & 3.91 & 11.56 \\
\hline Junior High & 28 & 4.76 & 16.33 \\
\hline Senior High & 330 & 56.12 & 72.45 \\
\hline College & 44 & 7.48 & 7.48 \\
\hline University (Bachelor) & 147 & 25.00 & 97.45 \\
\hline University (Master) & 15 & 2.55 & 100.00 \\
\hline Total & 588 & 100.00 & \\
\hline \multicolumn{4}{|l|}{ Occupation } \\
\hline Civil Servant & 36 & 6.12 & 6.12 \\
\hline Entrepreneur & 58 & 9.86 & 15.99 \\
\hline Housewife & 88 & 14.97 & 30.95 \\
\hline Laborer & 19 & 3.23 & 34.18 \\
\hline
\end{tabular}


Private Enterprise

Regional/State Owned

Enterprise

Retired

Student

Teacher/Lecturer

Unemployed

Total

\section{Status in Household}

Child

Grandfather

Grandmother

Husband

Wife

Total

JKN-KIS Membership

Registered (PBI)

Registered (not PBI)

Unregistered

Total

\section{5}

10

9

237

18

18

588

309

4

8

95

172

588

196

243

149

588
16.16

1.70

1.53

40.31

3.06

3.06

100.00

52.55

0.68

1.36

16.16

29.25

100.00

33.33

41.33

25.34

100.00
50.34

52.04

53.57

93.88

96.94

100.00

52.55

53.23

54.59

70.75

100.00

33.33

74.66

100.00

Source: Survey result

Assessment of respondents' health condition and outpatient care history before and during the Covid19 pandemic is displayed in Table 2.

Table 2. Health Condition and Outpatient Care History Before and During Covid-19 Pandemic

\begin{tabular}{|c|c|c|c|}
\hline Variable & Freq. & Percent $(\%)$ & Cum. $(\%$ \\
\hline \multicolumn{4}{|c|}{ Health Condition } \\
\hline \multicolumn{4}{|l|}{ Before Covid-19 } \\
\hline Did not experience any health problems & 438 & 74.49 & 74.49 \\
\hline Experienced health problems & 150 & 25.51 & 100.00 \\
\hline Total & 588 & 100.00 & \\
\hline \multicolumn{4}{|l|}{ During Covid-19 } \\
\hline Did not experience any health problems & 442 & 75.17 & 75.17 \\
\hline Experienced health problems & 146 & 24.83 & 100.00 \\
\hline Total & 588 & 100.00 & \\
\hline \multicolumn{4}{|c|}{ Outpatient Care History } \\
\hline \multicolumn{4}{|l|}{ Before Covid-19 } \\
\hline Did not access outpatient care & 437 & 74.32 & 74.32 \\
\hline Accessed outpatient care & 151 & 25.68 & 100 \\
\hline Total & 588 & 100.00 & \\
\hline During Covid-19 & & & \\
\hline
\end{tabular}




$\begin{array}{lccc}\text { Did not access outpatient care } & 498 & 84.69 & 84.69 \\ \text { Accessed outpatient care } & 90 & 15.31 & 100 \\ \text { Total } & 588 & 100.00 & \end{array}$

\title{
$\underline{\text { Reason(s) for Not Accessing Outpatient Care }}{ }^{1,2}$
}

\section{Before Covid-19}

$\begin{array}{lccc}\text { Self medication } & 26 & 31.71 & 31.71 \\ \text { Did not feel the need to } & 17 & 20.73 & 52.44 \\ \text { Insufficient means of transportation } & 3 & 3.66 & 56.10 \\ \text { Others } & 36 & 43.90 & 100.00 \\ \text { Total } & 82 & 100.00 & \\ \text { During Covid-19 } & & & \\ \text { Self medication } & 32 & 24.81 & 43.41 \\ \text { Did not feel the need to } & 27 & 20.93 & 64.34 \\ \text { Avoided contacting the Coronavirus } & 24 & 18.60 & 18.60 \\ \text { Others } & 46 & 35.66 & 100.00 \\ \text { Total } & 91 & 100.00 & \end{array}$

\begin{abstract}
Notes:
1. Figure only shows number of respondents who experienced health problems but did not access outpatient care.

2. The total number of reason(s) for not accessing outpatient care might differ from the total number of respondents not accessing outpatient care, as our questionnaire allows for respondents to state more than one reason(s).
\end{abstract}

\section{Source: Survey result}

Table 2 shows that $25.51 \%$ of our respondents experienced health problems before the Covid-19 pandemic and only $24.83 \%$ during the pandemic. The number of respondents who accessed outpatient care dropped from $25.68 \%$ to
$15.31 \%$ during the Covid-19 pandemic and the utilization of JKN-KIS for outpatient care also experiences a drop in frequency. To identify the statistical significance of these decreases, the paired t-test result is shown in Table 3 .

Table 3. JKN-KIS Utilization for Outpatient Care

\begin{tabular}{ccccc}
\hline & $\begin{array}{c}\text { Including respondents } \\
\text { who did not experience } \\
\text { health problems }\end{array}$ & $\begin{array}{c}\text { Excluding respondents } \\
\text { who did not experience } \\
\text { health problems }\end{array}$ \\
\hline Before Covid-19 & Freq. & $\%$ & Freq. & $\%$ \\
\hline $\begin{array}{c}\text { Utilizes JKN-KIS for outpatient care } \\
\text { Did not utilize JKN-KIS for outpatient } \\
\text { care }\end{array}$ & 84 & 55.63 & 49 & 53.85 \\
\hline
\end{tabular}




$\begin{array}{crrrr}\text { Not registered in JKN } & 31 & 20.53 & 22 & 24.18 \\ \text { Total } & 151 & 100.00 & 91 & 100.00\end{array}$

During Covid-19

Utilizes JKN-KIS for outpatient care 26

$\begin{array}{llll}26 & 28.89 & 27 & 43.55\end{array}$

Did not utilize JKN-KIS for outpatient

44

48.89

$19 \quad 30.65$

care

Not registered in JKN

20

22.22

16

25.81

Total

$90 \quad 100.00$

62

100.00

Source: Survey result

We divide Table 3 into two parts: the left side shows the overall number of respondents who accessed outpatient care, including those who did not experience health problems. Meanwhile, the right side of the table exclusively shows the number of those who experienced health problems and accessed outpatient care. The table shows an increase in the share of respondents who accessed outpatient care without utilizing JKN-KIS during the Covid-19 pandemic compared to before the pandemic.
Furthermore, the table shows a decrease in the share of respondents (including those who did not experience health problems) who utilized JKNKIS for outpatient care, from $55,63 \%$ before the pandemic to $28,89 \%$ during the pandemic. Also, the share of respondents who experienced health problems and utilized JKN-KIS for outpatient care faced a decrease from $53,85 \%$ before the Covid-19 pandemic to $43,55 \%$ during the pandemic

Table 4. Paired T-Test

\begin{tabular}{|c|c|c|c|}
\hline Variable & $\begin{array}{c}\text { One-Tailed } \\
\text { (L) } \\
\operatorname{Pr}(T<t)\end{array}$ & $\begin{array}{c}\text { Two-Tailed } \\
\operatorname{Pr}(|\mathrm{T}|>|\mathbf{t}|)\end{array}$ & $\begin{array}{c}\text { One-Tailed (U) } \\
\operatorname{Pr}(\mathbf{T}>\mathbf{t})\end{array}$ \\
\hline Health problems & 0.6287 & 0.7426 & 0.3713 \\
\hline Outpatient freq. & 1.0000 & $0.0000 * * *$ & $0.0000 * * *$ \\
\hline JKN-KIS for outpatient freq. & 0.9882 & $0.0235^{* *}$ & $0.0118^{* *}$ \\
\hline JKN-KIS outpatient care rejection & 0.2849 & 0.5698 & 0.7151 \\
\hline
\end{tabular}

Table 4 shows a significant decrease in the number of respondents who accessed outpatient care and the number of respondents who utilized JKN-KIS for outpatient care during the Covid-19 pandemic era. The number for both variables is significantly higher before the Covid-19 pandemic. It is interesting to note that even though there was no significant drop in the number of respondents who experienced health problems, the number of respondents who accessed outpatient care significantly decreases during the pandemic era. The univariate probit 
regression result to determine the factors affecting our respondents' tendency to access outpatient care is then shown in Table 5.

Table 5. Univariate Probit Regression

\begin{tabular}{|c|c|c|c|c|}
\hline \multirow{2}{*}{ Variables } & \multicolumn{2}{|c|}{ Before Covid-19 } & \multicolumn{2}{|c|}{ During Covid-19 } \\
\hline & Coefficients & Margins & During & Margins \\
\hline \multicolumn{5}{|c|}{ Age category } \\
\hline $15-30$ & - & - & - & - \\
\hline $31-45$ & $\begin{array}{c}0.600 * * \\
(0.249)\end{array}$ & $\begin{array}{l}0.114 * * \\
(0.0502)\end{array}$ & $\begin{array}{l}0.0593 \\
(0.355)\end{array}$ & $\begin{array}{l}0.00577 \\
(0.0350)\end{array}$ \\
\hline $46-60$ & $\begin{array}{l}0.413 * \\
(0.244)\end{array}$ & $\begin{array}{c}0.0750 \\
(0.0463)\end{array}$ & $\begin{array}{c}1.008 * * * \\
(0.276)\end{array}$ & $\begin{array}{c}0.140 * * * \\
(0.0426)\end{array}$ \\
\hline$>60$ & $\begin{array}{c}1.497 * * * \\
(0.391)\end{array}$ & $\begin{array}{c}0.330 * * * \\
(0.0938)\end{array}$ & $\begin{array}{c}1.860 * * * \\
(0.410)\end{array}$ & $\begin{array}{c}0.327 * * * \\
(0.0921)\end{array}$ \\
\hline Constant & \multicolumn{2}{|c|}{$\begin{array}{c}-1.364 * * * \\
(0.137)\end{array}$} & \multicolumn{2}{|c|}{$\begin{array}{c}-2.128 * * * \\
(0.179)\end{array}$} \\
\hline \multicolumn{5}{|c|}{ Marriage status } \\
\hline Single & - & - & - & - \\
\hline Married & $\begin{array}{c}0.465 * * \\
(0.200)\end{array}$ & $\begin{array}{c}0.0854 * * \\
(0.0367)\end{array}$ & $\begin{array}{c}0.631 * * \\
(0.249)\end{array}$ & $\begin{array}{c}0.0754 * * \\
(0.0300)\end{array}$ \\
\hline Widowed & $\begin{array}{c}1.571 * * * \\
(0.472)\end{array}$ & $\begin{array}{c}0.347 * * * \\
(0.114)\end{array}$ & $\begin{array}{c}1.947 * * * \\
(0.487)\end{array}$ & $\begin{array}{c}0.345^{* * * *} \\
(0.113)\end{array}$ \\
\hline Divorced & $\begin{array}{c}1.370^{* * *} \\
(0.595)\end{array}$ & $\begin{array}{c}0.297 * * \\
(0.146)\end{array}$ & $\begin{array}{l}1.454 * * \\
(0.641)\end{array}$ & $\begin{array}{l}0.229 * \\
(0.137)\end{array}$ \\
\hline Constant & \multicolumn{2}{|c|}{$\begin{array}{c}-1.370^{* * *} \\
(0.142)\end{array}$} & \multicolumn{2}{|c|}{$\begin{array}{c}-2.147 * * * \\
(0.187)\end{array}$} \\
\hline
\end{tabular}

Sex

Female

Male

$\begin{array}{llll}-0.102 & -0.0329 & -0.179 & -0.0422 \\ (0.116) & (0.0374) & (0.133) & (0.0312)\end{array}$




\begin{tabular}{ccc}
\hline \hline & & \\
Constant & $-1.000^{* * *}$ & $-1.596^{* * *}$ \\
& $(0.118)$ & $(0.139)$ \\
\hline
\end{tabular}

\section{Education}

Less than senior high graduate

At least senior high graduate

$$
\begin{array}{llll}
-0.0113 & -0.00215 & -0.0298 & -0.00386 \\
(0.0891) & (0.0170) & (0.118) & (0.0154)
\end{array}
$$

Constant

Occupation

Occupation $=0$,

Unemployed

Occupation $=1$,

Regional/State

Owned Enterprise

(0.327) (0.429)

Occupation $=2$,

Laborer

$\begin{array}{cccc}1.761 * * & 0.310 * * & 1.050 & 0.152 \\ (0.883) & (0.135) & (0.914) & (0.125)\end{array}$

Occupation $=3$,

Teacher/Lecturer

$\begin{array}{cccc}0.470 & 0.0556 & 0 & 0 \\ (0.982) & (0.115) & (1.062) & (0.105)\end{array}$

Occupation $=4$,

Housewife

$\begin{array}{cccc}0.693 & 0.0889 & -0.118 & -0.0111 \\ (1.091) & (0.147) & (1.295) & (0.120)\end{array}$

Occupation $=5$, Civil

servant

$\begin{array}{cccc}1.099 & 0.162^{*} & 0.0253 & 0.00253 \\ (0.788) & (0.0881) & (0.822) & (0.0815)\end{array}$

Occupation $=6$,

Private enterprise

$\begin{array}{cccc}1.258 & 0.194 * & 0.658 & 0.0833 \\ (0.833) & (0.107) & (0.861) & (0.0993)\end{array}$

Occupation $=7$,

Retired

$\begin{array}{cccc}1.257 & 0.194 * * & 0.483 & 0.0573 \\ (0.783) & (0.0879) & (0.799) & (0.0835)\end{array}$

Occupation $=8$,

$2.773 * * * \quad 0.556 * * * \quad 4.159 * * * \quad 0.778 * * *$

$\begin{array}{llll}(1.032) & (0.174) & (1.300) & (0.128)\end{array}$

Entrepreneur

$\begin{array}{cccc}1.026 & 0.148 & 0.838 & 0.113 \\ (0.808) & (0.0938) & (0.814) & (0.0922)\end{array}$

Occupation $=9$,

Student

$\begin{array}{cccc}0.786 & 0.104 & -0.0143 & -0.00141 \\ (0.767) & (0.0788) & (0.779) & (0.0769)\end{array}$

Constant 


\section{JKN-KIS Membership}

JKN-KIS Membership = 0, Unregistered

$\begin{array}{lcccc}\begin{array}{l}\text { JKN-KIS Membership = 1, Registered } \\ \text { (PBI) }\end{array} & 0.318 & 0.0573 & 0.113 & 0.0137 \\ & (0.259) & (0.0459) & (0.314) & (0.0378) \\ \begin{array}{l}\text { JKN-KIS Membership = 2, Registered } \\ \text { (not PBI) }\end{array} & 0.391 & 0.0718 & 0.269 & 0.0345 \\ & (0.248) & (0.0440) & (0.295) & (0.0369) \\ \text { Constant } & & & -1.864 * * *\end{array}$

\section{Robust standard errors in parentheses}

$* * * \mathrm{p}<0.01, * * \mathrm{p}<0.05, * \mathrm{p}<0.1$

Source: Team estimates

Table 5 contains the results of the univariate probit regression model. Based on the age group of the respondents, the results show that the older group has a higher probability of accessing outpatient care both before the pandemic period and during the pandemic. Based on the marital status, the group of respondents who are married, widowed, and divorced has a greater probability than single respondents. Furthermore, there is no significant difference between male and female respondents in accessing outpatient facilities. Our results also show that there is no significant difference between respondents with at least senior high graduate and less than senior high graduate.

Based on the type of work, residents who work as laborers, housewives, and retirees have a higher probability of accessing outpatient health facilities than respondents who do not work. This is different when a pandemic occurs. Only respondents who are retirees have a significant difference with unemployment. During the pandemic period, respondents with retired employment status had a greater probability of accessing outpatient health services. Furthermore, in terms of JKN ownership, there is no significant difference between respondents who are not JKN, PBI, and non-PBI members. This was consistent both before the pandemic and during the pandemic.

\section{Discussion}

Our analysis shows no significant difference in the respondents' health conditions before and during the Covid-19 pandemic. However, their frequency of seeking outpatient healthcare shows a significant decrease. One of the recorded reasons for this behavior being hesitancy to visit healthcare facilities due to fear of contacting the Coronavirus. Our result is in line with previous findings (Cavallo and Forman, 2020) that showed that outpatient care frequency tends to decrease in a much greater number compared to emergency and inpatient care. We also found the reasoning for this behavior to be similar to other studies (Kearns, 2020; NEJM Catalyst, 2020), stating that people tend to avoid accessing healthcare facilities altogether as a measure to avoid contacting the Coronavirus. 
Our results also show that the older population has a higher probability of accessing outpatient services. The regression results show that the population aged 46-60 and over 60 have no difference in accessing outpatient care both before the pandemic and during the pandemic. Outpatient services are not only needed for someone with health complaints, but also for those who carry out routine health checks. This often occurs in the older population. Furthermore, older residents have a greater probability of dying from covid-19 than younger residents. Therefore, special attention is needed by stakeholders to make policies, especially policies to regulate outpatient services for the elderly population.

Our analysis also shows a decrease in the use of JKN-KIS in outpatient services during the pandemic compared to before the pandemic. The decrease occurred in both respondents who had health complaints and not. This finding is in line with previous research. Rhatomy and Prasetyo (2020) state that there has been a decline in health-seeking behavior in primary care settings during the initial period of the pandemic. Declines in outpatient access during the pandemic also occurred in several countries such as Italy, Austria, Greece, Turkey, India, and Hong Kong. The decline, especially in primary services that occurred during the COVID-19 pandemic, could have an impact on the overall health status of the public. Their research also suggests that residents with minor health complaints are advised not to go to health facilities to reduce the risk of transmission. Residents are advised only to seek treatment if signs of certain health hazards are seen. The decline in health-seeking behavior during the COVID-19 pandemic could have an impact on the overall health status of the public.

\section{Conclusion}

The COVID-19 pandemic has changed people's behavior of seeking outpatient care. Risk exposure is one of the main reasons for people avoiding a visit to outpatient care. Our study concludes both less frequent use of Kartu Indonesia Sehat and the less frequent visit of outpatient care. Our study shed some light on outpatient care alternatives to maintain the health status of the community.

\section{References}

BPJS Kesehatan (no date) Manfaat Program JKN-KIS Makin Luas. Available at: https://bpjs-

kesehatan.go.id/bpjs/index.php/post/read/20 17/535/Manfaat-Program-JKN-KIS-MakinLuas (Accessed: 29 September 2020).

Cavallo, J. J. and Forman, H. P. (2020) 'The Economic Impact of the COVID-19 Pandemic on Radiology Practices', Radiology, 06520, p. 201495. doi: 10.1148/radiol.2020201495.

Conlon, C., McDonnell, T., Barrett, M. et al. The impact of the COVID-19 pandemic on child health and the provision of Care in Paediatric Emergency Departments: a qualitative study of frontline emergency care staff. $B M C$ Health Serv Res 21, 279 (2021). https://doi.org/10.1186/s12913-021-06284$\underline{9}$

Deloitte Indonesia (2020) Rising to the COVID19 Health Care Challenge in Indonesia. Available at: https://www2.deloitte.com/id/en/pages/lifesciences-and-healthcare/articles/rising-tocovid-19-health-care-challenge-inindonesia.html (Accessed: 10 August 2020).

https://data.unicef.org/resources/how-covid-19is-changing-the-world-a-statisticalperspective/ (Accessed: 01 June 2021)

Kearns, D. (2020) $22 \%$ of parents avoided accessing healthcare for their children over COVID-19 concerns, survey finds. Available at: https://medicalxpress.com/news/202007-parents-accessing-healthcare-childrencovid-.html (Accessed: 10 August 2020). 
Lind, D. A., Marchal, W. G., \& Wathen, S. A. (2012). Two Sample Tests of Hypothesis. In Statistical Techniques in Business and Economics (15th ed., pp. 392-395). McGraw-Hill.

National Economic Growth Impacted by COVID19 in Q2/2020 - Bank Sentral Republik Indonesia (no date). Available at: https://www.bi.go.id/en/iru/governmentpress-release/Pages/National-EconomicGrowth-Impacted-by-COVID-19-in-Q22020.aspx (Accessed: 29 September 2020).

NEJM Catalyst (2020) Where Are All the Patients? Addressing Covid-19 Fear to Encourage Sick Patients to Seek Emergency Care. Available at: https://catalyst.nejm.org/doi/full/10.1056/C AT.20.0193 (Accessed: 10 August 2020).

Satgas Penanganan COVID-19 (no date) Beranda. Available at: https://covid19.go.id/. Sholahuddin Rhatomy andThomas Edison Prasetyo (2020) Impact of COVID-19 on primary care visits: Lesson learnt from the early pandemic period, Journal of Community Empowerment for Health, Volume 3(2) August 2020,

Wooldridge, J. M. (2013). Limited Dependent Variable Models and Sample Selection Corrections. In Introductory Econometrics (5th ed., pp. 5853-585). Cengage Learning 